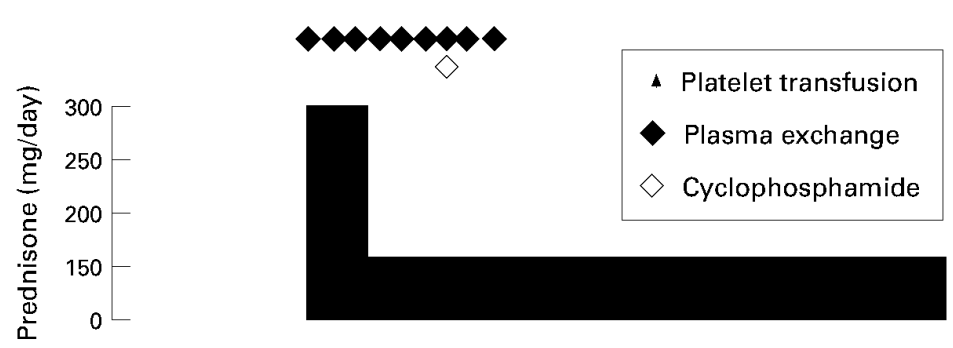

Heparin iv

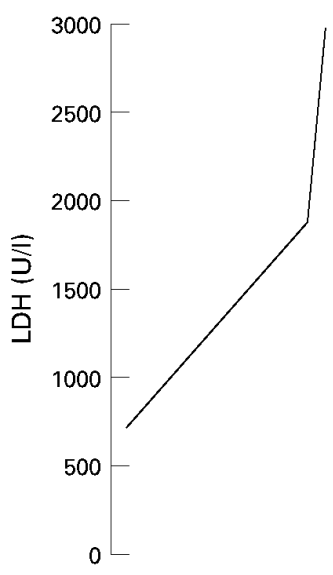

69369
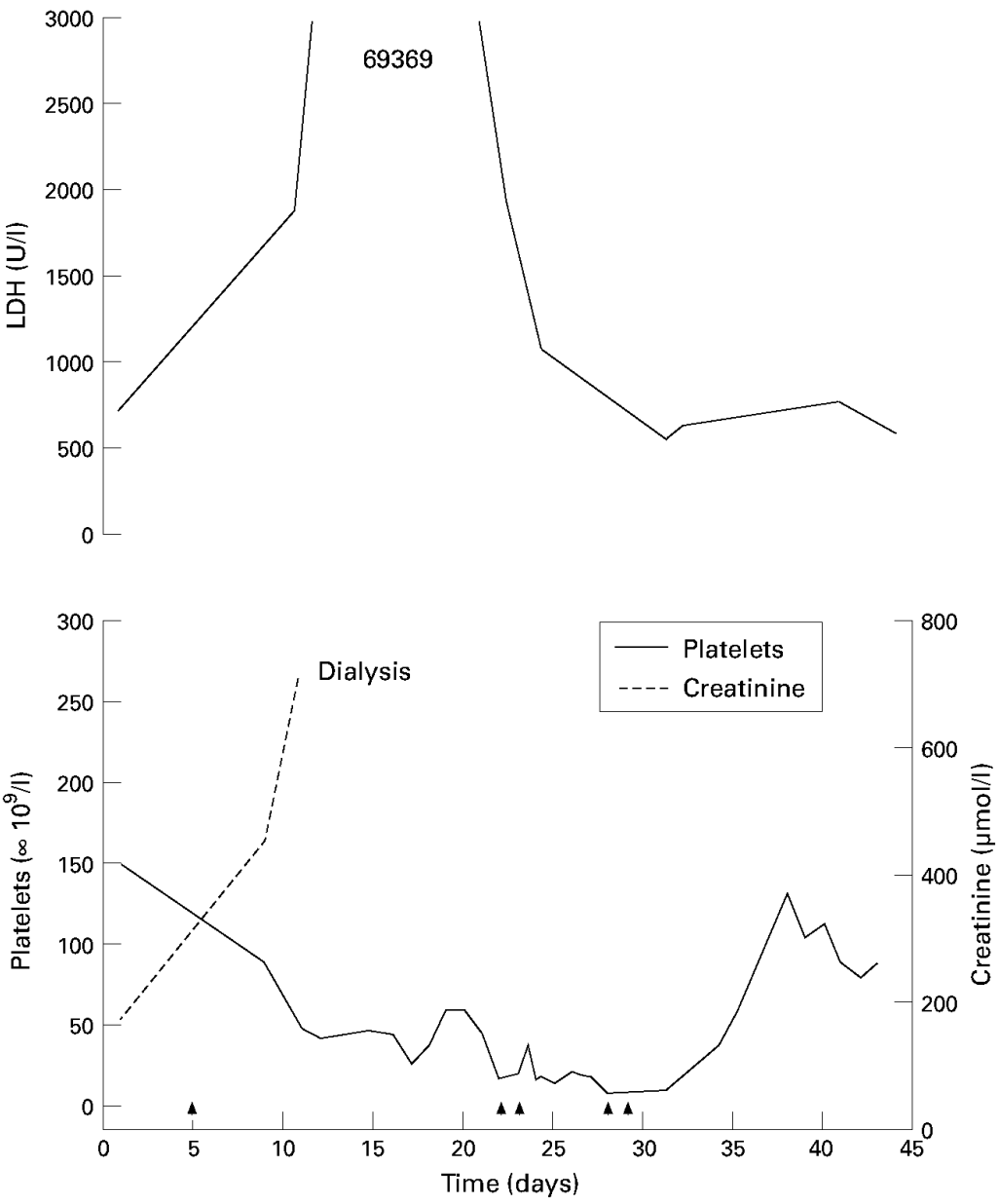

Figure 2 Course of essential laboratory data and treatment regimen of patient two.

1 Cervera R, Asherson RA, Lie JT. Clinicopathologic correlations of the antiphospholipid syndrome. Semin Arthritis Rheum 1995; 24:262-72.

2 Asherson RA. The catastrophic antiphospholipid syndrome. J Rheumatol 1992;19:508-12.

3 Asherson RA, Piette J-C. The catastrophic antiphospholipid syndrome 1996: acute multiorgan failure associated with antiphospholipid antibodies: a review of 31 patients. Lupus 1996;5:414-7.

4 Mazzucchelli R, Barbadillo C, Youssef H, Bernaldo De Quiros L, Mulero J, et al. Catastrophic antiphospholipid syndrome: a rare manifestation of the antiphospholipid antibody syndrome. Clin Exp Rheumatol 1993;11:653-7.

5 Cacoub P, Wechsler B, Piette JC, Beaufils H, Herreman G, Bletry O, et al. Malignant hypertension in antiphospholipid syndrome without tension in antiphospholipid syndrome without
overt lupus nephritis. Clin Exp Rheumatol 1993;11:479-85.
6 Peddi VR, Kant KS. Catastrophic secondary antiphospholipid syndrome with concomitant antithrombin III deficiency. J Am Soc Nephrol 1995;5:1882-7.

7 Voisin L, Derumeaux G, Borg JY, Mejiad O, Vittecoq O, Tayot J, et al. Catastrophic antiphospholipid syndrome with fatal acute course in rheumatoid disease. J Rheumatol $1995 ; 22: 1586-8$

8 Diaz-Coto JF, Barahona-Cuellar R. Catastrophic antiphospholipid syndrome. Presentation of a case. Rev Clin Esp 1995;195:29-30 9 Egan RM, Munn RK. Catastrophic antiphospholipid antibody syndrome presenting with

Table 1 The comparison of anti-HCV between the general population and patients with SLE

\begin{tabular}{llll}
\hline & Total $(n)$ & anti-HCV $(+)(n)$ & Frequency (\%) \\
\hline General population & 5257 & 77 & 1.4 \\
Patients with SLE & 38 & 1 & $2.6^{\star}$ \\
\hline
\end{tabular}

$\star \mathrm{p}>0.05$. (c100, 33c, c22) were assessed by the second generation Abbott enzyme linked immunosorbent assay (ELISA) according to manufacturer's instructions. It was estimated that the prevalence of anti-HCV antibodies (second generation ELISA) in the healthy population was $1.4 \%$ in our region. The $\chi^{2}$ test was used to perform statistical comparison. Table 1 shows the findings.

Anti-HCV was found to be positive in only one $(2.6 \%)$ patient. She was 33 years of age. multiple thromboses and sites of avascular necrosis. J Rheumatol 1194;21:2376-9.

10 Vivaldi P, Andreotti C, Mazzon C, Pedrazzoli M. A "primitive" catastrophic antiphospholipid syndrome. Haematologica 1994;79:173-6. 11 Hochfeld M, Druzin ML, Maia D, Wright J, Lambert RE, McGuire J. Pregnancy complicated by primary antiphospholipid antibody syndrome. Obstet Gynaecol 1994;83:804-5.

12 Ruffatti A, De Silvestro G, Ghirardello A, Calligaro A, Del Ross T, Thiene G, et al. A catastrophic antiphospholipid syndrome: the importance of high levels of warfarin anticoagulation. J Intern Med 1994;235:81-3.

13 Asherson RA, Cervera R, Font J. Multiorgan thrombotic disorders in systemic lupus erythematosus: A common link? Iupus 1992; 1:199-203.

14 Jain R, Chartash E, Susin M, Furie R. Systemic lupus erythematosus complicated by thrombotic microangiopathy. Semin Arthritis Rheum 1994;24:173-82.

\section{Prevalence of hepatitis C virus antibody in patients with systemic lupus erythematosus}

Systemic lupus erythematosus (SLE) is a disease of unknown aetiology characterised by impaired immune regulation and production of polyclonal autoantibodies. It is reported in the medical literature that in patients with chronic hepatitis resulting from hepatitis $\mathrm{C}$ virus (HCV) more autoantibodies such as antinuclear antibodies, anti-ds DNA, antiphospholipid antibody, antithyroglobulin antibody, rheumatoid factor, cryoglobulinaemia, and anti-GOR (an HCV induced, host derived epitope) are seen than in patients with other causes of hepatitis virus..$^{1-3}$ There have also been reports on HCV associated with several immunological diseases including membranoproliferative glomerulonephritis, ${ }^{4}$ polyarteritis nodosa, ${ }^{5}$ essential mixed cryoglobulinaemia, ${ }^{6}$ Sjögren's syndrome, ${ }^{7}$ and rheumatoid arthritis. ${ }^{8}$ There are not enough data, however, on the frequency of $\mathrm{HCV}$ infection in SLE cases. Therefore, we planned a study to investigate prevalence of anti-HCV in SLE cases.

Thirty eight patients ( 36 female) with SLE were included in the study. Their mean (SD) age was 31 (12) years (range 8-64). Diagnosis of SLE was made according to revised criteria of the American Rheumatology Association. ${ }^{9}$ The most common clinical and laboratory findings include arthralgia (59\%), fever $(58 \%)$, cutaneous manifestations $(20 \%)$, leucopenia (40\%), lupus nephritis $(65 \%)$, antinuclear antibodies (80\%), anti-DNA (49\%), and low values of C3 and C4 $(40 \%)$.

Antibodies against $\mathrm{HCV}$ encoded antigens 
No transmission risk was found except for spinal surgery one year before the symptoms and signs of the disease began. She had not received any blood, and there was no abnormality in the liver function tests during her follow up.

We found no significant difference between healthy population and SLE patients in terms of prevalence of anti-HCV ( $p>0.05)$. In the medical literature, we could not find any study about the prevalence of anti-HCV in SLE patients. However, Michel et al ${ }^{10}$ in their study about anti-GOR and $\mathrm{HCV}$ in autoimmune liver diseases have reported no anti-HCV in 10 SLE patients.

Our results showed that the prevalence of the anti-HCV in patients with SLE was not higher than that of the general population, and the relation between $\mathrm{HCV}$ and SLE could not be established.

YÜKSEL KARAKOC Department of Rheumatology

KAMIL DILEK MUSTAFA GÜLLÜLÜ MAHMUT YAVUZ ALPASLAN ERSOY

Department of Nephrology, Uludağ University Medical Faculty, Bursa

HALIS AKALYN Department of Clinical Microbiology and Infectious Disease, Uludağ University Medical Faculty, Bursa

MUSTAFA YURTKURAN Departments of Rheumatology and Nephrology, Uludağ University Medical Faculty, Bursa

Correspondence to: Dr K Dilek, Uludağ University Medical Faculty, Nephrology Department, 16059 Görükle, Bursa, Turkey.

1 Czaja AJ, Carpenter HA, Santrach PJ, Moore SB. Immunologic features and HLA association in chronic viral hepatitis. Gastroenterology 1995; 108:157-64.

2 Matsuda J, Saitoh N, Gotoh M, Gohchi K, Tsukamoto M, Syaji S, et al. High prevalence of anti-phospholipid antibodies and antianti-phospholipid antibodies and antithyroglobulin antibody in patients with hepati-
tis $C$ virus infection treated with interferontis C virus infection treated with interferon-
alpha. Am J Gastroenterol 1995;90:1138-41.

3 Dalekos GN, Manoussakis MN, Zervou E, Tsianos EV, Moutsopoulus HM. Immunologic and viral markers in the circulation of anti-HIV negative heroin addicts. Eur J Clin Invest 1993;23:219-25.

4 Johnson RJ, Gretch DR, Yamabe H, Hart J, Bacchi CE, Hartwell P, et al. Membranoproliferative glomerulonephritis associated with hepatitis $\mathrm{C}$ virus infection. $\mathrm{N}$ Engl $\mathrm{J}$ Med 1993;328:465-70.

5 Carson CW, Conn DL, Czaja AJ, Wright TL, Brecher ME. Frequency and significance of Brecher ME. Frequency and significance of nodosa. J Rheumatol 1993;20:304-9.

6 Lunel F, Musset L, Cacoub P, Frangeul L, Cresta $\mathrm{P}$, Perrin $\mathrm{M}$, et al. Cryoglobulinemia in chronic liver diseases: role of hepatitis $\mathrm{C}$ virus and liver damage. Gastroenterology 1994;106: 1291-300.

7 Haddad J, Deny P, Munz-Gotheil C, Ambrosini JC, Trinchet JC, Pateron D, et al. Lymhocytic sialadenitis of Sjögren's syndrome associated with chronic hepatitis $C$ virus liver disease. Lancet 1992;339:321-3.

8 Baffoni L, Frisoni M, Miniero R, Righetti F, Sprovieri G, Ferri S. Truepositive anti-HCV tests in rheumatoid arthritis. Br J Rheumatol 1993;32:349-50.

9 Tan EM, Cohen AS, Fries JF, Masi AT, Mcshane DJ, Rothfield NF, et al. The 1982 revised criteria for the classification of systemic lupus erythematosus. Arthritis Rheum 1982; 25:1271-7

10 Michel G, Ritter A, Gerken G, Meyer zum Büschenfelde KH, Decker R, Manns MP. Anti-GOR and hepatitis $C$ virus in autoimmune liver diseases. Lancet 1992;339:267-9.

\section{Gouty arthritis in the manubriosternal joint}

Gouty arthritis rarely involves anphiartrodial joints such as the manubriosternal joint. We report a case of recurrent manubriosternal joint (MSJ) pain in a patient with idiopathic, tophaceous chronic gouty arthritis.

A 52 year old man consulted for recurrent swelling of ankles, wrists, knees, and feet during the previous 12 years. His family doctor had previously made a diagnosis of gout, and intermitent colchicine and allopurinol 100 $\mathrm{mg} /$ day were prescribed. Despite treatment, however, he experience esisodes of gout three to four times a year and he stopped treatment. Alcohol intake was about 100 $\mathrm{g} /$ day. During the previous two years he was admitted twice to the emergency unit for intense, acute, anterior thoracic pain located on the sternum that lasted two or three days and was ameliorated by analgesics. Electrocardiograms and chest roentgenograms were reported to be normal.

Physical examination on the first visit showed that he was $15 \mathrm{~kg}$ overweight, tophi were present in both olecranon bursae, and limitation of the mobility of mid-feet, ankles, and wrists was present. Aspiration from tophi showed monosodium urate crystals under optical polarised microscopic examination. Roentgenograms disclosed signs of chronic gouty arthropathy in mid-feet. Plasmatic uric acid was $9.1 \mathrm{mg} / \mathrm{dl}$, clearance of urate 5.48 $\mathrm{ml} / \mathrm{min} / 1.73 \mathrm{~m}^{2}$, clearance of creatinine 123 $\mathrm{ml} / \mathrm{min} / 1.73 \mathrm{~m}^{2}$, urinary urate $726 \mathrm{mg} /$ day. Liver function tests and blood cell count were within normal limits. A hypocaloric (2000 $\mathrm{kcal} /$ day) alcohol free diet was prescribed, together with alopurinol $300 \mathrm{mg} /$ day and diclofenac $50 \mathrm{mg} /$ day.

Three weeks later he suffered acute gastroenteritis and a polyarticular gouty attack involving elbows, wrists, knees, and ankles and was admitted into hospital. Pain was also present on MSJ, and local soft tissue swelling was observed. A chest radiograph showed degenerative signs on the MSJ (fig 1). Aspiration of MSJ yielded a few drops of bloody fluid. Urate crystals were observed in a wet preparation under polarised examination, and in samples obtained from a knee. No

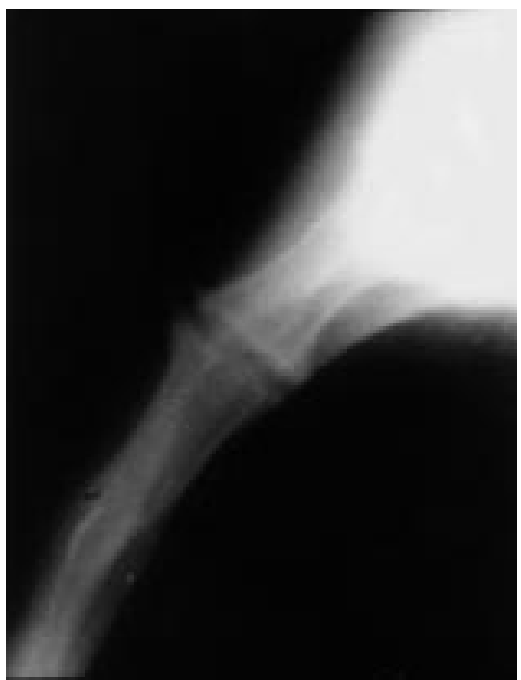

Figure 1 Lateral radiograph of the MSf (close up photograph), showing joint irregularities and prominent anterior and posterior osteophytes that suggest chronic arthropathy. microorganism was recovered from blood, stools or synovial fluid samples. Prednisone $20 \mathrm{mg} /$ day was prescribed with complete recovering in eight days. Then prednisone was gradually tapered (5 $\mathrm{mg}$ each five days). After a five year follow up, the patient is asymptomatic, tophi resolved, and plasmatic uric acid is $4.1 \mathrm{mg} / \mathrm{dl}$ with alopurinol 300 $\mathrm{mg} /$ day. No chest pain episodes have occurred during follow up.

Gouty arthritis most commonly locates in peripheral synovial joints. Involvement of spine, sacroiliac joints, symphysis pubis or thoracic wall is rare. ${ }^{1}$ The opposing oseus surfaces of the manubrium and the body of the sternum are covered by hyaline cartilage and separated by fibrocartilage; in one third of persons, this fibrocartilage cavitates and in $15 \%$ it may osify and form a synostosis. ${ }^{2}$ Gouty involvement of MSJ seems to be extremely uncommon: only two cases have been reported in the medical literature (MEDLINE search) in the past 10 years. $^{34}$ The rarity of MSJ involvement may be because of several reasons: firstly, only $30 \%$ of adults with chronic gout would show cavitation of MSJ that may predispose to urate crystal deposition; secondly, the more centrally a joint is located, the most uncommon is gouty involvement; thirdly, pain over the sternum in patients with chronic gout may be interpreted to be related to other causes and disappear with treatment for gout. In this case, as in both previously reported, ${ }^{34}$ urate crystals were observed in fluid aspirated from the MSJ. The patient observed by Shrewing and Carvell ${ }^{4}$ suffered recurrences despite appropriate treatment and underwent MSJ arthrodesis. Severe, progressive involvement of MSJ has also been reported in patients with pustulosis palmoplantaris ${ }^{5}$ and surgical treatment may be considered in such cases, ${ }^{4}$ but the present case also illustrates that some patients with poor control of serum urate concentrations may suffer from gouty attacks until proper treatment is started. ${ }^{6}$ Indeed, this patient was free of symptoms after weight control, alcohol withdrawal, ${ }^{8}$ and achieving urate concentrations of under $6 \mathrm{mg} / \mathrm{dl}$.

F PEREZ-RUIZ M CALABOZO
A ALONSO-RUIZ
Hospital de Cruces, Sección de Reumatología, Hospital de Cruces, Pza de Cruces s/n, 48903 Baracaldo, Vizcaya,
Spain

Correspondence to: Dr F Perez-Ruiz.

1 Resnick D, Niwayama G. Gouty arthritis. In: Resnick D, ed. Diagnosis of bone and joint disorders. Philadelphia: WB Saunders, 1995: 1535-8.

2 Resnick D, Niwayama G. Anatomy of individual joints. In: Resnick D, ed. Diagnosis of bone and joint disorders. ??: WB Saunders, 1995:699701 .

3 Kernodle GW Jr, Allen NB. Acute gouty arthritis presenting in the manubriosternal joint. Arthritis Rheum 1986;29:570-2

4 Shrewing DJ, Carvell JE. Arthrodesis for recurrent manubriosternal gout. J Bone Joint Surg Br 1991;73:341.

5 Jurik R. Monarthritis of the manubriosternal joint. A follow-up study. Rheumatol Int 1987; 7:235-41.

6 O'Reilly S, Doherty M. Missed opportunity following diagnosis of gout. Ann Rheum Dis 1995;54:86-7.

7 Nichols A, Scott JT. Effect of weight-loss on plasma and urinary levels of uric acid. Lancet 1972;ii: 1223-4.

8 Ralston SH, Capell HA, Sturrock RD. Alcoholic response to treatment of gout. BMJ 1988; 296:1641-2. 